\title{
Effects of increasing cold exposure on the oxygen uptake of walking unloaded and loaded
}

\author{
Katrina Hinde ${ }^{1 *}$, Carlton Cooke ${ }^{1}$, Ray Lloyd ${ }^{2}$ \\ From 15th International Conference on Environmental Ergonomics (ICEE XV) \\ Portsmouth, UK. 28 June - 3 July 2015
}

\section{Introduction}

Cold exposure and load carriage is an understudied area. Most research shows that $\mathrm{VO}_{2 \max }$ is generally unaffected by cold exposure, however the majority of research suggests that sub-maximal $\mathrm{O}_{2}$ consumption increases for a given workload [1]. This pilot study assessed the effects of cold on load carriage.

\section{Methods}

4 male participants (age: $21.8 \pm 3.4$ years, height: $182.5 \pm 5.0 \mathrm{~cm}$, weight: $77.8 \pm 13.5 \mathrm{~kg}$ ) completed a walking protocol of $\sim 1$ hour in a range of different ambient temperatures within an environmental chamber $\left(20{ }^{\circ} \mathrm{C}, 10{ }^{\circ} \mathrm{C}, 5{ }^{\circ} \mathrm{C}, 0{ }^{\circ} \mathrm{C},-5{ }^{\circ} \mathrm{C}\right.$ and $\left.-10{ }^{\circ} \mathrm{C}\right)$. Humidity was controlled at $\sim 50 \%$ while altitude was $0 \mathrm{~m}(20.95 \%$ $\mathrm{FiO}_{2}$ ). Participants wore shorts and $\mathrm{t}$-shirt for all trials. The protocol included a 15 minute rest period, unloaded walking at $4 \mathrm{~km} \cdot \mathrm{hr}^{-1}$ for 4 minutes at $0 \%$ and $10 \%$ gradient. The same workloads were repeated loaded $(18 \mathrm{~kg})$ after a 5 minute rest. Heart rate returned to resting levels before each exercise section to ensure prior activity did not influence findings. Unloaded walking was then repeated. Expired air was collected and analysed using a Cortex 3B Metalyzer (Germany). Statistical analysis was performed using SPSS version 22, with significance denoted by $\mathrm{p}<0.05$.

\section{Results}

Table 1 shows a significant increase in $\mathrm{VO}_{2}$ with load $(\mathrm{p}=0.019)$. At all workloads, significant increases in $\mathrm{VO}_{2}$ were associated with decreasing temperature $(\mathrm{p}=$ 0.048). $\Delta \mathrm{VO}_{2}$ values suggest that the effect of loading was consistent, regardless of ambient temperature $(\mathrm{p}=$ 0.997). When comparing the first unloaded exercise bout with the second, $\mathrm{VO}_{2}$ for $20{ }^{\circ} \mathrm{C}, 10{ }^{\circ} \mathrm{C}$ and $5{ }^{\circ} \mathrm{C}$ was similar, whereas at $0{ }^{\circ} \mathrm{C}$ and below, $\mathrm{VO}_{2}$ was higher in the second unloaded bout, but this interaction was not significant $(\mathrm{p}=0.158)$.

\section{Discussion}

The effect of ambient temperature on loading was not significant, however a decrease in temperature generally increased oxygen uptake. Reasons for a higher $\mathrm{VO}_{2}$ response during cold exposure could be due to shivering in an attempt to maintain core temperature [2]. However, the exercise intensity was above the estimated 1.5 L. $\mathrm{min}^{-1}$ threshold for the shivering response, therefore it is unlikely that this was the sole reason [3]. $\mathrm{VO}_{2}$ can be increased by non-shivering thermogenesis [4], this is heat production from sources excluding muscle contraction and involves calorigenic hormones and brown fat metabolism. Muscle strength has also been seen to decrease in cold environments through a decrease in contractile force $[1,5]$. More motor units are therefore recruited to meet the exercise demands, thus increasing $\mathrm{VO}_{2}$.

\section{Authors' details \\ ${ }^{1}$ School of Sport, Carnegie Faculty, Leeds Beckett University, Leeds, UK. \\ 2Leeds Trinity University, Leeds, UK.}

Published: 14 September 2015

\footnotetext{
References

1. Oksa J, et al: Journal of Thermal Biology 2004, 29(7-8):815-818.

2. Tharion W, et al: Appetite 2005, 44(1):47-65.

3. Sandsund M, et al: European Journal Of Applied Physiology And Occupational Physiology 1998, 77:297-304.

4. Ito $R$, et al: Effects if rain on energy metabolism while running in a cold environment. International Journal of Sports Medicine 2013, 34(8):707-711.

5. Doubt TJ: Sports Medicine (auckland, n.z.) 1991, 11(6):367-381.
} 
Table 1. Mean \pm SD $\mathrm{VO}_{2}$ responses $\left(\mathrm{ml} \mathrm{kg}^{-1} \cdot \mathrm{min}^{-1}\right)$ averaged across $0 \%$ and $10 \%$ gradient

\begin{tabular}{lrrrrrr}
\hline & $20{ }^{\circ} \mathrm{C}$ & \multicolumn{2}{c}{$5{ }^{\circ} \mathrm{C}$} & \multicolumn{2}{c}{$0{ }^{\circ} \mathrm{C}$} & \multicolumn{2}{c}{${ }^{\circ} \mathrm{C}$} & $-10{ }^{\circ} \mathrm{C}$ \\
\hline Unloaded 1 & $18.69 \pm 1.43$ & $18.99 \pm 1.52$ & $16.84 \pm 4.42$ & $19.30 \pm 2.38$ & $22.16 \pm 1.50$ & $22.99 \pm 1.09$ \\
\hline Loaded & $21.66 \pm 2.33$ & $23.76 \pm 0.41$ & $20.41 \pm 5.99$ & $24.43 \pm 4.06$ & $24.68 \pm 1.64$ & $27.44 \pm 4.13$ \\
\hline$\Delta \mathrm{VO}_{2}$ & $2.98 \pm 1.55$ & $4.78 \pm 1.26$ & $3.58 \pm 2.06$ & $5.13 \pm 3.84$ & $2.51 \pm 2.71$ & $4.45 \pm 4.55$ \\
\hline Unloaded 2 & $18.73 \pm 1.52$ & $19.03 \pm 0.66$ & $17.89 \pm 5.73$ & $23.41 \pm 7.72$ & $29.15 \pm 5.91$ & $28.25 \pm 5.53$ \\
\hline
\end{tabular}

doi:10.1186/2046-7648-4-S1-A56

Cite this article as: Hinde et al:: Effects of increasing cold exposure on

the oxygen uptake of walking unloaded and loaded. Extreme Physiology \& Medicine 2015 4(Suppl 1):A56.

Submit your next manuscript to BioMed Central and take full advantage of:

- Convenient online submission

- Thorough peer review

- No space constraints or color figure charges

- Immediate publication on acceptance

- Inclusion in PubMed, CAS, Scopus and Google Scholar

- Research which is freely available for redistribution

Submit your manuscript at www.biomedcentral.com/submit
C) Biomed Central 